\title{
VIII International Conference of Life Cycle Assessment in Latin America: CILCA 2019—Cartago, Costa Rica. July 15 to 20, 2019
}

\author{
Ana Quiros $^{1}$ (D) $\cdot$ Ana Arias $^{2}$ \\ Received: 19 July 2018 / Accepted: 21 August 2018 / Published online: 28 August 2018 \\ (C) Springer-Verlag GmbH Germany, part of Springer Nature 2018
}

One of the most recognized events by the life cycle community will be happening again, this time on July 2019 in Cartago, Costa Rica. We are referring to the International Conference of Life Cycle Assessment in Latin America, better known as CILCA, which convenes professionals, researchers, decision makers, and the public in general from different countries to interact and exchange experiences under the umbrella of life cycle thinking.

CILCA 2019 will be the eighth edition of this international event which has been rotating location, every 2 years, among the Latin American countries that conform the IberoAmerican Life Cycle Network (RICV). After 14 years since it started, it will be returning to where it originated in 2005 . Thereafter, the CILCA Conferences were conducted in Brazil (2007), Chile (2009), Mexico (2011), Argentina (2013), Peru (2015), and Colombia (2017). The 2019 international conference is jointly organized by RICV, Association for LCA in Latin America (ALCALA), and the Costa Rica National Life Cycle Network.

This CILCA 2019 has adopted as the overarching central topic "LCA: Global Competitiveness" to frame the discussions and exchanges on an array of sub-themes relevant to the regional context such as the following: life cycle and the international agreements; life cycle methodology and its applications to agriculture, building and energy sectors, fishing and marine litter, tourism, mining, procurement, education and lifestyles, just to name a few; as well as applicable tools such as eco-design and circular economy and much more. The structure of the international conference considers special meetings, courses, and workshops to be held just prior to

Ana Quiros

aquiros@ecoglobala.com

$\triangle$ Ana Arias

ana.lorena@itcr.ac.cr

1 ALCALA - GBCCR and ECO GLOBAL, San Jose, Costa Rica

2 TEC University Environmental Engineering, Cartago, Costa Rica
CILCA on July 15 and 16 . Opening Plenary is to happen on the morning of July 17 and continuing with other plenaries and parallel sessions up to July 19, with closing and award ceremonies. During the whole week, the showroom for CILCA-EXPO 2019 welcomes sponsors to promote their innovative products and services. On July 20, local organizers offer guided tours for those interested on technical and/or tourist visits to nearby sites.

As per other CILCAs, the participation of public and private organizations from all sectors and different countries, including researchers and decision makers, as well as students, is expected.

\section{Important dates and deadlines to keep in mind}

- Submission of abstracts (oral presentations and posters): Before October 30, 2018

- Notification of acceptance (oral presentations and posters): By December 14, 2018

- Submission of complete papers (for oral presentations): Before February 28, 2019

- Notification of acceptance (for oral presentations): By April 10, 2019

- Conference Activities: July 15-20, 2019

\section{Conference venue}

CILCA 2019 will be hosted at the University "Tecnológico de Costa Rica" (TEC), Central Campus, in Cartago. Cartago was the first capital of Costa Rica and the province is home to very interesting archeological sites, colonial ruins, and beautiful national parks. More information is available at www. cilca2019.org. 